\title{
Sustainability Reporting In The Accounting Curriculum
}

John W. Vann, (E-mail: jvann@bsu.edu), Ball State University Gwendolen B. White, (E-mail: gwhite@bsu.edu), Ball State University

\begin{abstract}
Seven class sections of undergraduate students in principles of managerial accounting courses participated in a study to examine the impact of sustainability accounting lectures with Internet assignments or lectures alone influence students' knowledge, skills, and attitudes toward sustainability reporting. The results of this study show that lectures with Internet assignments and lectures alone were equally effective in causing changes in the dependent measures compared to control groups who received no instruction on sustainability.
\end{abstract}

\section{INTRODUCTION}

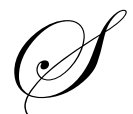

ustainability reporting (Triple-Bottom-Line Reporting) has become an integral part of business performance assessment. In its 2002 triennial survey of corporate reporting, KPMG states that sustainability reports are becoming widespread (KPMG 2002). Users of corporate information are no longer content with financial reports alone. The demand for additional indicators about corporate economic, environmental, and social performance (hence the term Triple-Bottom-Line) has been driven by stockholder initiatives supported by the Coalition for Environmentally Responsible Economies (CERES 2004), by stock indices such as FTSE4GOOD (2004a) and the Dow Jones Sustainability Indexes (DJSI 2004), and by the requirements of ISO 14001 (ISO 2004).

Many corporations are currently measuring, recording, reporting, and using information on financial, social, and environmental performance. The triple-bottom-line reporting trend has been led by pioneering firms such as Interface, Inc, Electrolux, and Bristol Meyers Squibb, but has been adopted by many other corporations as well. Evidence of this trend can be found on a website produced by Next Step Consulting (2004), a consulting firm based in London. This website contains a searchable data base with thousands of social and environmental reports. Sustainability reports may also be viewed on the web sites for Green@Work (2004), International Corporate Environmental Reporting (2004), and the World Business Council for Sustainable Development SD Reporting Portal (WBCSD 2004).

A parallel focus on sustainable performance has developed in the investment community, beginning with Socially Responsible Investing (SRI) and moving to include broader sustainability issues. For example, the Interfaith Center on Corporate Responsibility and its membership of 275 faith-based institutional investors collectively manage portfolios with a combined value of about $\$ 110$ billion, and urge companies to be socially and environmentally responsible (ICCR 2004). There has been a concomitant development of "green" mutual funds.

There is evidence that sustainability reporting affects the stock price of firms. For example, Botoson (1997) found that under some circumstances (for "firms that attract a low analyst following" (p. 323)) higher disclosure levels are associated with lower cost of capital. In a recent study by Dowell, Hart, and Yeung (2000), firms that adopted a stringent global environmental standard rather than a less stringent standard had a higher market value.

Society's increased expectations of corporations and the business world's response make obvious the need for all business majors, and especially accounting majors, to be knowledgeable about sustainability reporting. This includes knowing the frameworks and systems for recording sustainability performance, the internal accounting and 
reports for managing that performance, and external reports to relevant stakeholders. Incorporating this topic into the curriculum addresses the recommendations of the Accounting Education Change Commission (1998) and the CPA Vision Project (AICPA 2004). The CPA Vision Project views being "Attuned to Broad Business Issues" to be one of the top 5 core values that CPAs should possess. More specifically, "CPAs are in tune with the overall realities of the business environment" (AICPA 2004b). To achieve this objective, accounting/business curricula need to be updated with content on sustainability reporting.

Including sustainability reporting in the curriculum may pose some problems for accounting educators. Grinnell and Hunt (2000) found that a separate course on environmental accounting required a substantial investment in time by the faculty. They found that textbooks dedicated to environmental accounting were not available. In addition, many undergraduate programs have no room for a separate, required course on sustainability reporting.

This paper illustrates where and how sustainability reporting can be easily incorporated into principles of managerial accounting. A course in principles of managerial accounting appears to be an appropriate place to introduce sustainability accounting because students in this course have usually completed a course in principles of financial accounting. At this stage, students understand the basics of financial reporting and the uses of corporate financial reports. Sustainability reporting is a logical extension of corporate financial reporting. It also follows that learning about the management of environmental costs is compatible with learning about many of the traditional topics (e.g., activity-based costing) in managerial accounting. Providing information for the management of environmental costs is part of the function of the managerial accountant. Discussion of how environmental management accounting and ISO 14001 relate to sustainability reporting is well suited to this course.

The purpose of this paper is to demonstrate how sustainability measurement and reporting can be introduced to accounting/business majors with the express purpose of increasing their knowledge, skills, and positive attitudes toward sustainability reporting. The paper presents the results of a study of the impact on those outcomes of lectures on sustainability measurement and reporting presented alone or in concert with internet assignments. Lecture Power Point files and Internet assignments are available from the authors on request.

\section{BACKGROUND}

\section{Life-Cycle Assessment}

Triple-bottom line reporting has its roots in life-cycle assessment (LCA), which began in the 1970s. LCA still provides a useful framework for identifying triple-bottom-line impacts. LCA tracks the impact of business activity from raw materials extraction through manufacturing, use, and final disposition. Impacts are classified into resource depletion, human health, and environmental health. Human wellbeing beyond health issues traditionally has not been covered nor have economic impacts. The focus of LCA has been primarily on individual products or services rather than on overall companies or facilities. LCA also affected the conceptual development of the ISO 14000 family of environmental management system guidelines (Tibor and Feldman 1996). Tracking of impacts throughout the life cycle of products and services was followed by the development of formalized environmental management systems (EMSs).

\section{Environmental Management Systems}

Environmental Management Systems have been created to help companies manage their environmental costs. They are established not only to comply with environmental regulations, but also to help companies reduce and prevent environmental costs. ISO 14000 is a framework developed by the International Organization for Standardization (ISO) that has received worldwide acceptance (ISO 2004). At the end of 2000, 22,897 environmental certificates were held in 98 countries (ISO no date).

To receive ISO 14001 certification, a firm must have an environmental management system in place that meets ISO criteria. These include measuring and reporting to stakeholders on environmental performance. 
Certification acknowledges the presence of an appropriate management system and not of appropriate performance. However, the assumption is that measuring and reporting on environmental performance will lead to enhancement of that performance (Tibor and Feldman 1996). ISO 14001 certification has become a de facto requirement for conducting business in the European Union. In addition, since one of the criteria of certification is to encourage suppliers to become certified, certification by large corporations such as the major auto manufacturers in the United States causes a cascading series of certifications among smaller firms.

\section{Managerial Benefits of Sustainability Measurement and Reporting}

Kaplan's and Norton's (1996) Balanced Scorecard approach to strategic planning and performance measurement employs multiple perspectives in addition to financial dimensions for setting objectives. Integration of environmental and social dimensions into this framework is currently being pursued (Zingales, O'Rourke, and Hockerts 2002). Clearly, triple-bottom-line reporting is well suited to accommodate these additional dimensions. The Environmental Capital Markets Committee of The National Advisory Council for Environmental Policy and Technology (2000) reported that corporate views of environmental issues have evolved to a strategic value-creation perspective involving product innovation, market redefinition, and the creation of barriers to market entry instead of earlier focus on compliance and environmental management.

By identifying the environmental costs and tracing them to their sources, companies can produce relevant information for engineers, production personnel, and marketing staff to help keep their products competitive (Kreuze and Newell, 1994). Many leading companies have recognized the importance of measuring environmental costs and are accounting for them as an intrinsic part of corporate decision-making (Hamner and Stinson, 1995). By assigning the environmental costs to the products or processes that create them, companies can motivate the responsible managers and employees to find pollution prevention alternatives that lower costs and increase profitability (EPA 1995). The advent of activity-based costing and life-cycle costing enables the identification and measurement of specific environmental costs. As a result, companies can evaluate environmental activities and attempt to eliminate costs that do not add value to their products (Kreuze and Newell, 1994).

\section{The Emergence of Standardized Sustainability Reporting}

The efforts to increase sustainability reporting have been led by the Coalition for Environmentally Responsible Economies (CERES) since its formation in 1989. In 1997, in partnership with the United Nations Environment Programme CERES started the Global Reporting Initiative (GRI) whose purpose is:

... to elevate sustainability reporting to the same level of rigour, comparability, credibility, and verifiability expected of financial reporting, while serving the information needs of a broad array of stakeholders from civil society, government, labour, and the private business community itself (Global Reporting Initiative 2002, p. 1)

The Sustainability Reporting Guidelines were published in 2000 and revised in 2002. They recommend measures within all three domains of sustainability. They are currently followed by many companies and other institutions (Global Reporting Initiative 2004a). The University of Florida Sustainability Indicators August 2001 was "Published in Accord with The Global Reporting Initiative Sustainability Reporting Guidelines, June 2000" (Chesnes and Newport 2000, front cover). In a list updated April 23, 2004, the Global Reporting web site profiles 439 companies in 43 countries that are following the guidelines in their reporting. These companies include: Anheuser-Busch Companies; AT\&T; BASF; Body Shop International; Bristol-Myers Squibb; British Airways; Canon; Chiquita Brands; Electrolux; Ford Motor Company; Fuji Xerox; General Motors; Johnson \& Johnson; KLM Royal Dutch Airlines; Konica; Marathon Oil; Nike; Nissan; Nokia; Procter \& Gamble; Shell International; Siemens; and Volvo Car Corporation (Global Reporting Initiative 2004a). The Guidelines may be downloaded in PDF format in seven different languages (Global Reporting Initiative 2004b).

Major accounting firms have also recognized the importance of sustainability reporting. Deloitte Touche Tohmatsu has participated in efforts to develop the Global Reporting Initiative and have recently published the "Deloitte Sustainability Reporting Scorecard" (Deloitte, Touche, Tohmatsu 2002). They provide guidance to their 
clients on sustainability issues such as Climate Change; Environment \& Eco-efficiency; People: Corporate Social Responsibility; and Sustainable Emerging Markets (2004).

Sustainability reporting is being encouraged and rewarded through the granting of CERES-ACCA Sustainability Reporting Awards (CERES-ACCA 2004). These awards are granted to ". . .reward best practice in reporting on sustainability, environmental and social issues by United States and Canadian corporations and other organizations and to provide guidance to other entities that are publishing or intend to publish sustainability reports" (CERES-ACCA 2004).

\section{Corporate Adoption of Sustainability Reporting}

The triple-bottom-line reporting trend has been led by pioneering firms such as Interface, Inc, Electrolux, and Bristol Meyers Squibb, but has been adopted by many other corporations as well. 3M's perspective is expressed by W. James McNerney, Jr., their Chairman of the Board and CEO (McNerney 2004):

For a hundred years, the people of $3 M$ have provided innovative and useful products to generations of satisfied customers. 3Mers have also recognized that the company's long-term success springs from adopting and implementing the principles of sustainable development: stewardship to the environment, contributions to society and to the creation of economic value and worth.

Next Step Consulting, a consulting firm based in London, has produced a web site (2004) that has a data base with thousands of social and environmental reports, searchable by company name, business sector, affiliation (such as with UK FT 250, the Coalition for Environmentally Responsible Economies (CERES), the World Business Council for Sustainable Development (WBCSD)), and/or country. Sustainability reports may also be viewed on the web sites for Green@Work (2004) and International Corporate Environmental Reporting (2004) . Broad guidance on sustainability reporting is provided by the WBCSD through their Sustainable Development Reporting Portal (WBCSD 2004).

In its 2002 triennial survey of corporate reporting (KPMG 2002), KPMG's results demonstrate that sustainability reporting and the verification of these reports by the GFT250 (top 250 of the Global Fortune 500 companies) and Top 100 companies (in 19 countries) is becoming mainstream business. Reporting practices are no longer restricted to sectors with a high environmental impact in Western countries, but also in non-industrial sectors and other regions. The survey results show that there has been a significant increase in the number of companies issuing environmental, social or sustainability reports, in addition to their annual financial reports. In 2002, almost half of the GFT250 (45\%) and just under a third of the Top 100 companies (28\%) produce these reports compared to $35 \%$ and $24 \%$ in 1999 respectively (KPMG 2002).

\section{The Emergence of Investor-Targeted Sustainable-Performance Indices - FTSE4GOOD and Dow Jones Sustainability Indexes}

While the Global Reporting Initiative (GRI) has spearheaded the development of guidelines, guidelines are also implicit in the requirements for membership in the FTSE4GOOD (2004b) and the Dow Jones Sustainability World Indexes (DJSI World). These indexes list companies that have passed screening criteria for sustainable performance. The DJSI World indexes identify “. . . the top 10\% of the companies in the Dow Jones Global Index that lead the field in terms of corporate sustainability" (DJSI 2003, P. 6). These ". . consist of more than 300 companies that represent the top $10 \%$ of the leading sustainability companies in 60 industry groups in the 34 countries covered by the biggest 2500 companies in the Dow Jones Global Indexes" (DJSI 2004b).

These indexes are based on the following assumptions:

Corporate Sustainability is a business approach to create long-term shareholder value by embracing opportunities and managing risks deriving from economic, environmental and social developments. Corporate sustainability leaders harness the market's potential for sustainability products and services while at the same time successfully 
reducing and avoiding sustainability costs and risks. A growing number of investors perceives sustainability as a catalyst for enlightened and disciplined management, and, thus, a crucial success factor. As a result, investors are increasingly diversifying their portfolios by investing in companies that set industry-wide best practices with regard to sustainability (DJSI 2003, p. 7).

The index is based on a Corporate Sustainability Assessment process that uses criteria to evaluate the opportunities and risks confronted by an organization in the economic, environmental, and social arenas. General criteria are used for all firms and specific criteria are used for different industry groups. Measures on each criterion are weighted and an overall corporate sustainability performance score is calculated using both the general and group specific criteria. See Table 1 for examples of the Corporate Sustainability Assessment Criteria.

Table 1 DJSI Corporate Sustainability Assessment Criteria

\begin{tabular}{|l|l|}
\hline Dimension & \multicolumn{1}{|c|}{ Criterion } \\
\hline Economic & Codes of Conduct/Compliance/Corruption\&Bribery \\
\hline & Corporate Governance \\
\hline & Customer Relationship Management \\
\hline & Financial Robustness \\
\hline & Investor Relations \\
\hline & Risk \& Crisis Management \\
\hline & Scorecards/Measurement Systems \\
\hline & Strategic Planning \\
\hline & Industry Specific Criteria \\
\hline & Environmental Policy/ Management \\
\hline & Environmental Performance \\
\hline & Environmental Reporting \\
\hline & Industry Specific Criteria \\
\hline & Corporate Citizenship/ Philanthropy \\
\hline & Stakeholder Engagement \\
\hline & Labor Practice Indicators \\
\hline & Human Capital Development \\
\hline & Knowledge Management/Organizational Learning \\
\hline & Social Reporting \\
\hline & Talent Attraction \& Retention \\
\hline & Standards for Suppliers \\
\hline & Industry Specific Criteria \\
\hline & \\
\hline &
\end{tabular}

11.

Data sources for the assessment include a Corporate Sustainability Assessment Questionnaire distributed by SAM Research and available online (2003). This questionnaire is an excellent source for students to examine so that they may see the exact nature of the questions. The results of the questionnaire are given less weight in the Corporate Sustainability Assessment if not signed by senior management of the firm being examined. In addition to the questionnaire, company documents are examined, as is publicly available information from the company or the media. Finally, companies are contacted personally for clarifying questions. 


\section{Reporting on the Internet}

Companies are now frequently producing web pages that present their triple-bottom line performance. In addition, they are often including links on their web sites that access published reports available as PDF downloads. Electronic reporting of triple-bottom-line performance represents a new opportunity for communicating with stakeholders. However, as with any medium, there are criteria for assessing a sustainability reporting web site in terms of its quality from a communications perspective.

In Ethical Corporation magazine, Lynne Elvins describes "Best Practices for Online Reporting in Corporate Responsibility," (2002). Elvins paper more directly considers the sustainability content of online reports and profiles the online reports of selected corporations. This and the other preceding information provide both the justification and the framework for the lectures and assignments that were tested.

\section{METHOD}

\section{Treatments}

Lectures. The topics selected for inclusion in the lectures are relevant to sustainability reporting from both internal and external reporting perspectives. Although many more topics could be covered, the topics selected are prevalent in business practice. The lectures covered life-cycle assessment; environmental management systems (EMS), including ISO 14001; sustainability reporting in accordance with the Global Reporting Initiative (GRI) Reporting Guidelines; the Dow Jones Sustainability Index (DJSI); and Reporting on the Internet.

Internet Assignments. The assignments required the use of the Internet because many companies are posting their reports on this medium. Students completed the assignments individually. Three different assignments were used, but were the same within class sections. While the content was not systematically manipulated, these assignments represent a range of activities through which interested parties may access or review on-line sustainability reports.

One assignment simply requires the student to evaluate a specific online corporate sustainability report following certain guidelines. The second requires that the student compare the online sustainability reports for two different corporate reports in terms of their reporting of specified dimensions. The third assignment requires that students become familiar (via the http://www.sustainability-index.com site) with the SAM questionnaire used by the Dow Jones Sustainability Index for assessing firms. Students were then required to compare the Market Sector Leaders in Automobiles from the DJSI World Link (DJSI 2004c) for 2002 and 2003 in terms of their reported sustainability performance. These assignments have the added advantage of incorporating the use of technology into the curriculum. (The assignments are available from the authors on request.)

\section{Dependent Measures}

Dependent measures were collected through the use of an ad hoc questionnaire developed for this study. The questionnaire includes questions for assessing knowledge and attitudes. Skills in applying knowledge regarding sustainability reporting were inherently measured through the completion of the internet assignments. There was no attempt to measure application skills for the other conditions. Consequently, this dependent variable is not assessed in this study.

Knowledge. Twenty-one multiple-choice questions were used to assess knowledge regarding sustainability measurement and reporting. These questions addressed general issues and dimensionality of reporting and of environmental management systems (EMSs) along with specific knowledge of the Global Reporting Initiative, ISO14001, and life-cycle assessment (see the Appendix). As a dependent variable for analysis, Knowledge was measured as the number of correct responses across the 21 questions. 
Attitude. Three questions using a desirability scale were used to assess student attitudes toward the use of sustainability reports as "a way of influencing stakeholder relations," "managing corporate operations," and "improving sustainability performance." Answers to these three questions were treated independently in the analysis.

\section{HYPOTHESES}

The objectives of this study were to assess the impact of lectures and Internet assignments on the knowledge, skills, and attitudes toward sustainability reporting. It was hypothesized that the lectures alone and lectures with Internet assignments would both lead to greater student knowledge regarding sustainability measurement and reporting than that of students in control groups who received neither lectures nor assignments. It was also hypothesized that lectures alone and lectures with Internet assignments would both lead to more positive attitudes toward the use of sustainability measurement and reporting than attitudes of students in control groups with neither lectures nor assignments. It was hypothesized that the addition of Internet assignments would lead to greater student learning and more positive attitudes than for students in the lecture-only conditions.

\section{PROCEDURES}

\section{Subjects}

Participants in this study were 122 undergraduates enrolled in 7 sections of introductory managerial accounting in a college of business at a regional state university in the mid-western United States. Introductory managerial accounting is a required course for all majors in this college of business. The university's Institutional Review Board (IRB) approved this study. All participants signed informed consent forms.

\section{Experimental Conditions}

Each of the seven sections was assigned one treatment condition. Two sections received the lecture only. Three sections received the lecture with each section receiving a different Internet assignment. Two class sections served as a control and received neither the lecture nor the Internet assignments. Students in all five sections receiving the lectures were told that they would be tested over the material covered in the lectures. The assignments (available on request from the authors) involved using the Internet to complete specific tasks related to sustainability reporting.

\section{Treatment Manipulation and Data Collection}

One of the authors delivered the same lecture (delivered with the same PowerPoint slides) to the five treatment groups. A week after the lectures were given and the assignments had been collected, a graduate assistant administered the sustainability questionnaire (See the Appendix) to all seven groups. The graduate assistant explained that the two authors were conducting research on sustainability reporting and asked for their voluntary participation in completing the questionnaire. Participants' responses were anonymous. All students agreed to participate and signed an informed consent form.

\section{Results}

Table 2 includes means for knowledge and attitude dependent measures across conditions. Observed effects on these variables are described below.

Effects on Knowledge. To test for the effects on knowledge, the mean number of correct responses was compared across conditions. Analysis of variance $\left(\mathrm{F}_{6,115}=23.719\right)$ showed significant differences across conditions for this criterion $(\mathrm{p}<.001)$. Planned comparisons were conducted to establish whether the hypothesized differences were present. The first contrast comparing groups with lecture and internet assignments with lecture-only groups was not significant $\left(\mathrm{t}=.59, \mathrm{p}_{\mathrm{two}-\text { tailed }}=.56\right)$. The second contrast compared those with lecture and internet 
assignments with the control groups. This comparison showed that lecture and internet assignments together significantly increased the knowledge measure $\left(\mathrm{t}=11.70, \mathrm{p}_{\mathrm{two} \text {-tailed }}<.001\right)$. The third contrast compared lectureonly groups with the control groups. Lecture-only groups scored significantly higher on the knowledge test than the control groups $\left(\mathrm{t}=7.27, \mathrm{p}_{\mathrm{two} \text {-tailed }}<.001\right)$. The fourth contrast compared all treatment groups against the control groups. The treatment groups were significantly different from the control $\left(\mathrm{t}=11.14, \mathrm{p}_{\mathrm{two}-\text { tailed }}<.001\right)$. In summary, lecture and internet groups were not significantly different from the lecture only groups, but the lecture and internet and the lecture only groups separately and combined were significantly higher than the control groups.

Table 2 Knowledge and Attitude Mans by Condition

\begin{tabular}{|l|c|c|c|c|}
\hline \multicolumn{1}{|c|}{ Condition } & $\begin{array}{c}\text { Number Correct } \\
\text { out of 21 }\end{array}$ & $\begin{array}{c}\text { Desirability for } \\
\text { influencing } \\
\text { Stakeholder } \\
\text { Relations }\end{array}$ & $\begin{array}{c}\text { Desirability for } \\
\text { managing } \\
\text { Corporate } \\
\text { Operations }\end{array}$ & $\begin{array}{c}\text { Desirability for } \\
\text { Improving } \\
\text { Sustainability } \\
\text { Performance }\end{array}$ \\
\hline Lecture and evaluate reports (n=25) & 17.24 & 4.84 & 5.04 & 5.17 \\
\hline Lecture and compare two firms (n=18) & 16.78 & 4.76 & 4.94 & 5.11 \\
\hline Lecture and DJSI (n=22) & 15.68 & 4.76 & 5.05 & 5.35 \\
\hline Lecture Only A (n=13) & 15.0 & 4.67 & 4.77 & 4.92 \\
\hline Lecture Only B (n=9) & 17.22 & 5.11 & 5.11 & 5.00 \\
\hline Control A (n=16) & 9.56 & 5.17 & 4.82 & 5.45 \\
\hline Control B (n=19) & 8.95 & 4.14 & 4.64 & 4.40 \\
\hline
\end{tabular}

Effects on Attitude. Analysis of Variance was conducted across groups on each of the attitude measures. There were no significant effects on any of the three measures. When the planned comparisons were conducted, none of them was significant either. In summary, the treatments had no significant effect on "Desirability for influencing stakeholder relations," "Desirability for managing corporate operations," nor "Desirability for improving sustainability performance."

\section{Discussion}

Strong effects of lecture alone and lecture with internet assignments were observed on student knowledge regarding sustainability reporting while attitudes toward sustainability reporting were unaffected. The results for knowledge are very encouraging. Accounting professors may elect to use lectures either alone or with internet assignments and can expect success in student knowledge outcomes. Given the emergent importance of sustainability reporting, professors may use the attached lectures or ones of their own to develop student understanding in this area.

The lack of impact on student attitudes is troublesome. It was expected that the desirability of sustainability reporting for multiple purposes would have been apparent from the lectures and/or assignments. Attitudes may have been initially high prior to the treatments. The control groups have means above four on a sixpoint scale. There could also be a ceiling effect since with initial means above four, there is not much room for treatment means to be differentiated from the controls. There is also the possibility that a social desirability bias played a role in the responses, with the students responding in a positive way to please the researchers.

\section{CONCLUSION}

This study demonstrates that sustainability reporting can be easily incorporated into a beginning managerial accounting course. In addition, the resources available for adding the material to this course are easily accessible from the Internet. If time does not permit within a curriculum, professors can present lectures without assignments. Students in this study learned about sustainability reporting as well with or without assignments. Sustainability reporting should be incorporated into the business curriculum so that accounting/business majors can be prepared to 
understand more than just traditional financial and managerial reports. Students need to know the current informational demands being placed on firms.

Firms are now being held accountable for their performance on the triple-bottom-line. Measurement and reporting of financial, environmental, and social dimensions of performance has become an essential part of communicating with various stakeholders, both with print and on-line Internet reports. Preparation and comprehension of these reports are aided by the many measurement and reporting guidelines that are currently available on the World Wide Web. Many of these include downloadable guides for implementation. These guides are valuable resources that can help accounting students to understand the framework for sustainability reporting and to become knowledgeable about measurement and reporting implementation. Accounting professors may use the assignments provided in this paper or those of their own invention for their students to gain fluency in sustainability reporting. There is an emergent need for accounting students to be knowledgeable about sustainability reporting. The use of assignments that require that students access, evaluate, and use these guidelines can help to accomplish this goal.

\section{REFERENCES}

1. ACCA and Next Step Consulting, Ltd (2001). Electronic Environmental, Social and Sustainability Reporting on the World Wide Web: A Guide to Best Practice. [Publication online.] London: The Certified Accountants Educational Trust. Accessed 5 Feb. 2002. Available online: http://www.nextstep.co.uk/PDF/ PUBLICATIONS/PUBLICATIONS.pdf. Internet.

2. Accounting Education Change Commission (1998). "The Future Viability of AAA Members' Programs," Report of the Changing Environment Committee," American Accounting Association, July 15, 1998. [Publication online.] Accessed 13 May 2004. Available online: http://aaahq.org/about/reports/ chngenv98.htm. Internet.

3. AICPA (2004a). "CPA Vision Project: 2011 and Beyond." [Publication online.] American Institute of Certified Public Accountants (AICPA). Accessed 13 May 2004. Available online: http://www.cpavision.org. Internet.

4. $\quad$ AICPA (2004b). "Top Fives" - Values, Services, Competencies, and Issues for the Future." [Website online.] American Institute of Certified Public Accountants (AICPA). Accessed 13 May 2004. Available online: http://www.cpavision.org/vision.htm. Internet.

5. Botosan, Christine A. (1997). "Disclosure Level and the Cost of Equity Capital," The Accounting Review, 77 (3), 323-349.

6. CERES (2004). Coalition for Environmentally Responsible Economies. [Website online.] Accessed 13 May 2003. Available online. http://www.ceres.org/. Internet.

7. CERES-ACCA (2004). "CERES-ACCA Sustainability Reporting Awards." Coalition for Environmentally Responsible Economies (CERES) and the Association of Chartered Certified Accountants (ACCA). Accessed 13 May 2004. Available online: http://www.ceres.org/our_work/2003_repawards.htm. Internet.

8. Chesnes, Tom, and Dave Newport (2000). University of Florida Sustainability Indicators August 2001. The Greening UF Program.

9. Deloitte, Touche, Tohmatsu (2004). "Issues Management." [Website online.] Deloitte \& Touche Global Environmental Services. Accessed 13 May 2004. Available online: http://www.deloitte.com/dtt/ section_node/0,2332,sid\%253D1086,00.html. Internet.

10. Deloitte, Touche, Tohmatsu (2002). Deloitte Sustainability Reporting Scorecard [Publication online.] Deloitte \& Touche Global Environmental Services. Accessed 19 December, 2002. Available online: http://www.deloitte-Sustainable.com/Reporting/FullScorecardpdf.pdf.

11. DJSI (2004a). Dow Jones Sustainability Indexes. [Website online.] Accessed 13 May 2004. Available online: http://www.sustainability-index.com/. Internet.

12. DJSI (2004b). "Key Facts - DJSI World." [Website online.] Accessed 13 May 2004. Available online: http://www.sustainability-index.com/htmle/djsi_world/keyfacts.html. Internet.

13. DJSI (2004c). "Market Sector Leaders - DJSI World". Accessed 13 May 2004. Available online http://www.sustainability-index.com/htmle/djsi_world/msectorleaders.html. Internet. 
14. DJSI (2003). "Dow Jones Sustainability World Indexes Guide Version 5.0, September 2003." [Publication online.] Accessed 13 May 2004. Available online: http://www.sustainabilityindex.com/djsi_pdf/publications/DJSI_WORLD_Guidebooks/DJSI_World_Guidebook_50.pdf. Internet.

15. Dowell, Glen, Stuart Hart, and Bernard Yeung (2000). "Do Corporate Global Environmental Standards Create or Destroy Market Value?" Management Science, 2000, Vol 46: pp 1059-1074.

16. Elvins, Lynne (2002). "Best Practices for Online Reporting in Corporate Responsibility." [magazine article online] Ethical Corporation. Accessed 5 February 2002. Available online: http://www.ethicalcorp.com/ NewsTemplate.asp?IDNum=172. Internet.

17. EPA (1995). An Introduction to Environmental Accounting As a Business Management Tool: Key Concepts and Terms (EPA 742-R-95-001). Office of Pollution Prevention and Toxics, US. Environmental Protection Agency, Washington, D. C.

18. FTSE4GOOD (2004a). [Website online.] Accessed 11 May 2004. Available online: http://www.ftse.com/ ftse4good/index.jsp. Internet.

19. FTSE4Good (2004b). "FTSE4Good Index Series Inclusion Criteria." [Publication online.] Accessed 13 May 2004. Available online: http://www.ftse.com/ftse4good/FTSE4GoodCriteria.pdf. Internet.

20. Global Reporting Initiative (2004a). "Organisations Using the Guidelines." Accessed 13 May 2004. Available online: http://www.globalreporting.org/guidelines/companies.asp. Internet.

21. Global Reporting Initiative (2004b). "Translations." Accessed 13 May 2004. Available online: http://www.globalreporting.org/guidelines/translations.asp. Internet.

22. Global Reporting Initiative (2002) "Introducing the 2002 Sustainability Reporting Guidelines" [Publication online.] Accessed 14 November 2003. Available online: http://www.globalreporting.org/guidelines/2002/ gri_companion_lite.pdf. Internet.

23. Green@Work (2004). [Website online.] Accessed 11 May 2004. Available online: http://www.greenatworkmag.com/cer/index.html. Internet.

24. Grinnell, D.J. and H.G. Hunt III. (2000). "Development of an Integrated Course in Accounting: A Focus on Environmental Issues." Issues in Accounting Education (February): 19-42.

25. Hamner, B. and Stinson, C.H. (1995). "Managerial Accounting and Environmental Compliance Costs." Journal of Cost Management. Summer, 4-10.

26. ICCR (2004) Interfaith Center on Corporate Responsibility. [Website online.] Accessed 13 May 2004. Available online: http://www.iccr.org/. Internet.

27. International Corporate Environmental Reporting (2004). [Website online.] Accessed 11 May 2004. Available online: http://www.enviroreporting.com, Internet.

28. ISO (no date). "The ISO Survey of ISO 9000 and ISO 14000 Certificates - Tenth Cycle," [Publication online.] Accessed 11 November 2003. Available online: http://www.iso.ch/iso/en/iso900014000/pdf/survey10thcycle.pdf, Internet.

29. ISO (2004). "ISO 14000." [Website online.] Accessed 13 May 2004. Available online: http://www.iso.org/iso/en/iso9000-14000/iso14000/iso14000index.html. Internet.

30. Kaplan, R. and D. Norton (1996). The Balanced Scorecard. Boston: Harvard Business School Press.

31. KPMG (2002) "KPMG International Survey of Corporate Sustainability Reporting 2002." [Publication online.] Accessed 11 November 2003. Available online: http://www.wimm.nl/publicaties/KPMG2002.pdf. Internet.

32. Kreuze, J. G. and Newell, G. E. (1994) "ABC and Life-Cycle Costing Environmental Expenditures" Management Accounting. February, 38-42.

33. McNerney, W. James, Jr. (2004). "Letter from the Chairman \& CEO" in 3M's Environmental, Social and Economic Sustainability Report. [Publication online]. Accessed 13 May 2004. Available online: http://www.3m.com/about3m/sustainability/ceo.jhtml

34. National Advisory Council for Environmental Policy and Technology (2000) "Green Dividends? The Relationship Between Firms' Environmental Performance and Financial Performance." [Publication online.] EPA Environmental Capital Markets Committee of the National Advisory Council for Environmental Policy and Technology. Accessed 13 May 2004. Available online: http://www.epa.gov/ocem/nacept/green_dividends.pdf. Internet.

35. Next Step Consulting (2004). [Website online.] Accessed 11 May 2004. Available online: http://www.corporateregister.com. Internet. 
36. SAM Research (2003). Corporate Sustainability Assessment Questionnaire. [Publication online.] SAM Research. Accessed 13 May 2004. Available online: http://www.sustainabilityindexes.com/djsi_pdf/Questionnaire_2003.pdf. Internet.

37. Tibor, Tom and Ira Feldman (1996). Implementing ISO 14000. New York: McGraw-Hill.

38. WBCSD (2004). "WBCSD's SD Reporting Portal." Accessed 11 May 2004. Available online: http://www.wbcsd.org/includes/getTarget.asp?type=e\&id=http://www.sdportal.org/templates/Template3/la yout.asp?MenuId=360

39. Zingales, F.,A. O'Rourke, and K. Hockerts (2002). "Balanced Scorecard and Sustainability: State of the Art Review," Working Paper, The Centre for the Management of Environmental Resources, INSEAD. Available online: http://www.insead.edu/CMER/publications/wp/ Zingales\%20ORourke\%20Hockerts\%202002\%20R+D\%2065\%20Balanced\%20scorecard.pdf.

\section{APPENDIX}

\section{Sustainability Questionnaire}

Instructions

If you would like to participate in this research survey, please read the informed consent form. If you agree to participate, sign the informed consent form. Do not put your name on this questionnaire.

Part 1 - Circle the best answer.

1. Which item below best represents the current view of sustainability?

a. It refers to a company's long-term maintenance of market share.

b. It is the long-term survivability of economic, environmental, and social systems.

c. It is the long-term survivability of environmental systems.

d. Sustainability includes whatever means are necessary to obtain financial objectives.

2. Measuring the sustainable development of an organization

a. is important because of increased human impacts on the environment.

b. is not important because we have technology that will correct environmental damage done by humans.

c. does not consider that there is a trade-off between a company's economic, environmental, and social activities.

d. is not relevant to a company's reputation.

3. Over 3000 corporate environmental, social or sustainability reports have been published. This is happening because

a. corporations are responding to a demand for a higher standard of corporate accountability.

b. governments are requiring it.

c. accountants are creating more work for themselves.

d. Generally Accepted Accounting Principles require it to supplement financial statements.

4. The Global Reporting Initiative (GRI) is

a. an agency of the United States government in the Treasury Department responsible for setting standards for sustainable reporting.

b. an international organization setting standards for sustainable reporting.

c. the part of the sustainability section of the Financial Accounting Standards Board (FASB).

d. a division of the U. S. Environmental Protection Agency setting standards for environmental reporting.

5. Sustainability reporting is required by

a. Financial Accounting Standards Board (FASB).

b. Global Reporting Initiative (GRI).

c. Securities and Exchange Commission (SEC).

d. No organization because it is voluntary. 
6. Sustainability Reporting Guidelines have the following components:

a. economic, financial, and social.

b. financial and environmental.

c. international, environmental, and social.

d. economic, environmental, and social.

7. Which of the following indicators would be measures of an organization's social performance?

a. labor practices and decent work, human rights, society, and product responsibility

b. net sales, cost of goods sold, market sectors, and total payroll

c. air emissions, solid waste sent to landfill, and water usage

d. total products produced in different markets

8. Sustainability reporting guidelines apply to

a. only organizations that are large, international corporations.

b. only federal government agencies.

c. only universities and municipalities.

d. organizations of all types, sizes, and locations.

9. Firms adopt sustainability as a goal in order to

a. create long-term shareholder value by embracing opportunities and managing risks deriving economic, environmental, and social outcomes.

b. create short-term shareholder value by embracing opportunities and managing risks from only economic events.

c. create long-term shareholder value by making products that are most profitable in the short-term.

d. create long-term shareholder value by sustaining their current market share by exploiting opportunities and managing risks to generate economic outcomes.

10. Firms that are recognized in the top $10 \%$ of leading sustainability companies can be classified as

a. part of the Dow Jones Sustainability Index (DJSI).

b. meeting the sustainability goals of the Securities and Exchange Commission (SEC).

c. part of the FTSE4Good Index.

d. a member of the President's Council for Sustainable Development

11. The Dow Jones Sustainability Index (DJSI)

a. is an agency of the U. S. government

b. is a subdivision of the Securities and Exchange Commission.

c. meets the sustainability requirements of Financial Accounting Standards Board.

d. identifies organizations with superior sustainability performance.

12. What would be an important source of information to assess a company's sustainability performance?

a. sustainability reports required in audited financial statements

b. sustainability information in a company's prospectus

c. sustainability information collected through a standardized questionnaire

d. a company's sustainability mission statement

13. An organization that creates and implements an environmental management system (EMS) can have its system certified in accordance with

a. ISO (International Organization of Standards) 14001 standards

b. Generally Accepted Accounting Principles (GAAP) in the United States of America.

c. United States Environmental Protection Agency (EPA).

d. Securities and Exchange Commission (SEC)

14. Organizations which wish to have their environmental management system (EMS) recognized globally need to be certified under

a. United Nations Environmental Programme (UNEP)

b. Global Reporting Initiative (GRI)

c. ISO (International Organization of Standards) 14001

d. Financial Accounting Standards Board (FASB) 
15. For an environmental management system to be effective, which of the following must happen in an organization?

a. Top management must endorse the policy.

b. Only management needs to be aware of the policy.

c. It should only be used by internal management and need not be submitted for external review.

d. Must follow Securities and Exchange Commission (SEC) guidelines.

16. Which item below is not considered a potential benefit of having a certified environmental management system?

a. helps companies comply with environmental regulations

b. reduce wastes and cut costs

c. improves the environment

d. securing the Environmental Protection Agency's endorsement

17. Which of the following is one of the purposes of a certified environmental management system?

a. creating an environmental fund to pay for environmental damages

b. seeking customer recognition of the company's environmental management system

c. seeking approval of the Institute of Management Accountants

d. seeking ways to reduce income taxes

18. Life-cycle analysis of products focuses on the environmental impacts of a product

a. during manufacturing and final disposal.

b. during final disposal of the product at the end of its life cycle.

c. during its life from raw material extraction to final disposition.

d. during the useful life of the product after the consumer purchases it.

19. . When a company implements life-cycle management of their products, they

a. are more likely to increase their criminal liability exposure for damage to the environment

b. are more likely to increase stockholder value with increased revenue and market share.

c. are not likely to enhance their public image.

d. are likely to decrease their competitiveness because the implementation requires more company resources than are warranted.

20. Life-cycle management considerations are limited to examination of which of the following consequences?
a. economic
b. economic and environmental
c. economic, environmental, and social
d. environmental and social

21. Sustainability Reporting provides information to
a. only stockholders of a corporation.
b. all stakeholders
c. only creditors of a corporation
d. internal management.

\section{Part II}

Please write a check mark in the spaces that indicate your assessments of the desirability of using sustainability reports for various purposes.

1. How desirable is a sustainability report as a way of influencing stakeholder relations?

\begin{tabular}{|c|c|c|c|c|c|}
\hline $\begin{array}{c}\text { Extremely } \\
\text { Desirable }\end{array}$ & $\begin{array}{r}\text { Somewhat } \\
\text { Desirable }\end{array}$ & Desir & & & \\
\hline
\end{tabular}


2. How desirable is the use of sustainability reports for managing corporate operations that affect sustainability performance?

\begin{tabular}{|c|c|c|}
\hline $\begin{array}{c}\text { Extremely } \\
\text { Desirable }\end{array}$ & Somewhat & $\overline{\text { Desirabl }}$ \\
\hline
\end{tabular}

3. How desirable is sustainability reporting in improving the sustainability performance of a corporation?

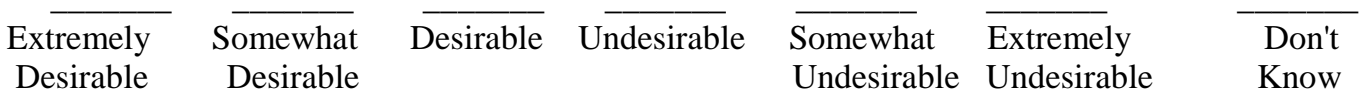

Notes 